\title{
MINERAL RESOURCE POTENTIAL OF THE TTALIAN PEAK AND TTALIAN PEAK MIDDLE ROADLESS AREAS, BEAVERHEAD COUNTY, MONTANA, AND CLARK AND LEMHI COUNTIES, IDAHO
}

By

\author{
Betty Skipp, John C. Antweiler, and Dolores M. Kulik, U.S. Geological Survey \\ and \\ Robert H. Lambeth and Ronald T. Mayerle, U.S. Bureau of Mines
}

\section{STUDIES RELATED TO WILDERNESS}

Under the provisions of the Wilderness Act (Public Law 88-577, September 3, 1964) and related acts, the U.S. Geological Survey and the U.S. Bureau of Mines have been conducting mineral surveys of wilderness and primitive areas. Areas officially designated as "wilderness," "wild," or "canoe" when the act was passed were incorporated into the National Wilderness Preservation System, and some of them are presently being studied. The act provided that areas under consideration for wilderness designation should be studied for suitability for incorporation into the Wilderness System. The mineral surveys constitute one aspect of the suitability studies. The act directs that the results of such surveys are to be made available to the public and be submitted to the President and the Congress. This report discusses the results of a mineral survey of the Italian Peak Roadless Area in the Beaverhead National Forest, Beaverhead County, Montana, and the Italian Peak Middle Roadless Area, Targhee National Forest, Clark and Lemhi Counties, Idaho. The Italian Peak (I1945) and Italian Peak Middle (M4945) Roadless Areas were classified as further planning areas during the Second Roadless Area Review and Evaluation (RARE II) by the U.S. Forest Service, January 1979.

\section{MINERAL RESOURCE POTENTIAL SUMMARY STATEMENT}

The Italian Peak Roadless Area (I1945) and the Italian Peak Middle Roadless Area (M4945), together referred to as the study area (and also as the Italian Peak Roadless Areas), have been evaluated by a multidisciplinary team of geoscientists, and the potential for several types of undiscovered mineral resources has been classified. Five areas show low or moderate mineral resource potential for base metals, silver, uranium, and vanadium.

In the northwestern part of the study area, low mineral resource potential for silver, molybdenum, lead, and zinc is present in the granites and syenites of the Beaverhead Mountains pluton. In the west-central part of the study area, in the northern part of the Birch Creek mining district, moderate to low resource potential for stratabound silver and base metals is present primarily in dolomite of the Devonian Jefferson Formation. Production of silver-lead-zinc ore valued at as much as $\$ 5$ million has been recorded for the Birch Creek mining district, mainly from the Viola mine less than $2 \mathrm{mi}$ from the study area; no production has been recorded for the roadless areas. Low to moderate mineral resource potential for silver and base metals also is present in and around Tertiary faults in Mississippian limestones in the west-central part of the area. In the east-central part of the study area, low to moderate mineral resource potential for stratabound and fault-controlled silver and base metals concentrations is present. In the northeastern part of the study area, low mineral resource potential exists for silver and base metals in local stratabound diagenetic dolomite in the lower part of the Upper Mississippian Scott Peak Formation. In the southern part of the study area, low to moderate mineral resource potential for stratabound uranium and vanadium, and possibly, silver and base metals occurs in metal-rich, sheared and brecciated siltstones and shales of the Devonian Three Forks Formation and the Mississippian McGowan Creek Formation. The eastern part of the study area has low resource potential for gas at depth. The potential for placer gold and geothermal resources also were evaluated, but no resources were identified. A quarry northeast of the study area contains a resource for decorative travertine stone, but no travertine deposits are recognized in the area itself.

\section{INTRODUCTION}

Location and topography

The Italian Peak (11945) and Italian Peak Middle (M4945) Roadless Areas comprise approximately 12,996 and 42,500 acres, respectively, in the
Beaverhead National Forest, Beaverhead County, Mont., and the Targhee National Forest, Clark and Lemhi Counties, Idaho (fig. 1). The areas are contiguous along the Continental Divide, which is also the Idaho-Montana State boundary. They have similar geology and mineral resource potential, and, for the purpose of this report will be referred to collectively 


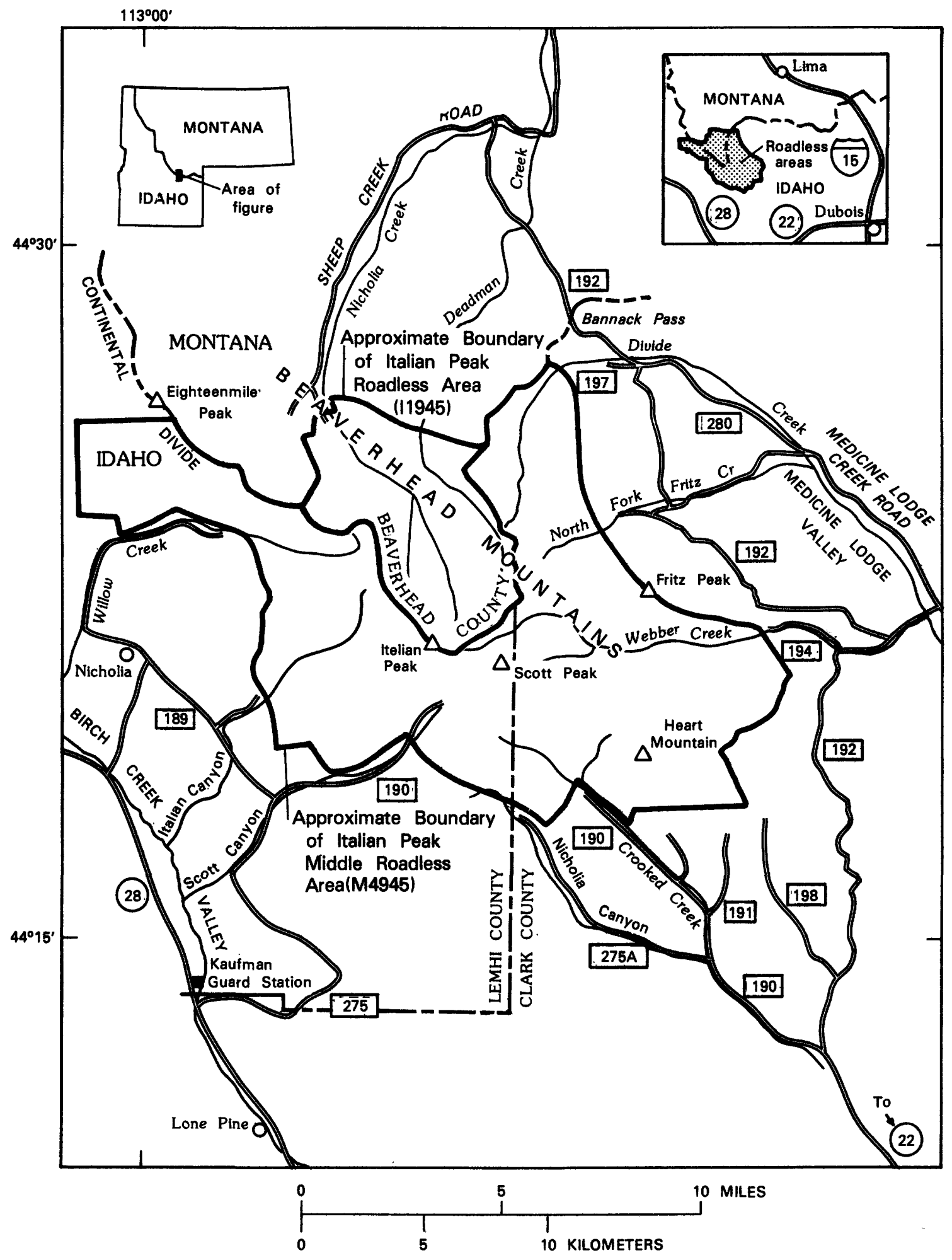

Figure 1.--Index map of the Italian Peak and Italian Peak Middle Roadless Areas, Beaverhead County, Mont., and Clark and Lemhi Counties, Idaho. 
as the study area (and also as the Italian Peak Roadless Areas).

The Italian Peak Roadless Areas are located in the southern Beaverhead Mountains about $17 \mathrm{mi}$ southwest of Lima, Mont., and about $25 \mathrm{mi}$ northwest of Dubois, Idaho (fig. 1). The study area is covered entirely by U.S. Geological Survey 15-minute series topographic quadrangle maps. The borders of the area are irregular and are defined by the Targhee Forest boundary on the northwest, parts of the Continental Divide on the north, and segments of township and range and section lines on the east and south. Several segments of the boundary follow drainages.

Access to the perimeter of the area is provided by Sheep Creek Road in Montana, and Medicine Lodge Creek Road and Idaho State Highway 28 in Idaho. Forest Service development roads and numerous pack trails provide interior access (fig. 1).

The Continental Divide enters the northwestern part of the study area, loops southward about $7 \mathrm{mi}$ into the central part, exits northward through the northcentral part, and then turns east. Several major peaks, including Italian Peak $(10,998 \mathrm{ft})$ make up the divide and stand well above timberline, which occurs at about $9,600 \mathrm{ft}$ in this vicinity. Other major peaks, including Scott Peak $(11,393 \mathrm{ft})$, the highest point in the area, lie southeast of the Continental Divide. Maximum relief in the area is about $4,600 \mathrm{ft}$, and annual rainfall averages 16-32 in. (U.S. Geological Survey, 1970). Major drainages in Montana are Bear, Tendoy, Nicholia, Deadman, and Little Deadman Creeks. In Idaho, the major drainages are Divide, Fritz, Webber, Myers, Crooked, Willow, and Eighteenmile Creeks and Grouse, Nicholia, Scott, and Irish Canyons.

\section{Previous studies}

Previous regional geologic studies of all or parts of the area include: Umpleby (1913); Kirkham (1927); Scholten and others (1955); Ramspott (1962); Scholten and Ramspott (1968); Skipp and Hait (1977); and Skipp, Prostka, and Schleicher (1979). Studies of the Birch Creek mining district include: Umpleby (1913); Shenon (1928); and Anderson and Wagner (1944). Uranium mineralization of the area south of Heart Mountain is discussed in Wodzicki and Krason (1981).

\section{Present study}

This report summarizes the results of a mineral survey of the study area from 1980 to 1982 conducted jointly by the U.S. Geological Survey and the U.S. Bureau of Mines. All of the 55,496 acres encompassed in the study area are U.S. Forest Service lands in southwesternmost Montana and east-central Idaho. The U.S. Geological Survey, using geological, geochemical, and geophysical techniques, investigated the extent of mineralization associated with mines and propects in the study area and defined areas having low to moderate potential for resources of lead, zinc, silver, uranium, and vanadium. The U.S. Bureau of Mines examined, mapped, and sampled all prospects to determine their mineral resource potential.

Results from this investigation of the Italian Peak Roadless Areas are described in studies on the geology (Skipp, in press); geochemical surveys (Antweiler and others, in press); aeromagnetic data (U.S. Geological Survey, 1981); gravity and aeromagnetic data (Kulik, in press); and an investigation of mines, prospects, and mineralized areas (Lambeth and Mayerle, 1983).

\section{Acknowledgments}

The U.S. Geological Survey and U.S. Bureau of Mines are grateful to the staff of the U.S. Forest Service District Office of the Targhee National Forest in Dubois, Idaho, for providing facilities, information, and aerial photographs, and for aiding in communications. U.S. Geological Survey personnel also wish to thank Mrs. Adelaide Mitchell of Lima, Mont., for providing facilities and an historical perspective of the area, and Andrew L. Schumacher who compiled most of the illustrations for this report.

\section{GEOLOGY AND STRUCTURE}

The Italian Peak Roadless Areas are part of the northern projection of the Idaho-Wyoming thrust belt across the Snake River Plain. Three major thrust plates, made up of the hanging walls of the Hawley Creek, Fritz Creek, and Cabin thrusts, comprise the study area (fig. 2), and they are thought to have moved in Late Cretaceous time at least several miles from southwest to northeast to their present positions in the Beaverhead Mountains (fig. 1) (Scholten and Ramspott, 1968; Ryder and Scholten, 1973; Skipp, Prostka, and Schleicher, 1979; Skipp, in press). Allochthonous marine Proterozoic $\mathrm{Y}$ (Middle Proterozoic) and Paleozoic rocks make up all three plates. Thrusts trend generally northwest and are offset in places by east-west-trending tear faults formed during thrusting. Some east-west-trending faults also appear to have had younger movement.

North-northwest- to northwest-trending, premiddle Eocene Tertiary and Quaternary normal faults (Skipp, in press) cut preexisting structures and most autochthonous continental Tertiary volcanics and interbedded basin-fill sediments and sedimentary rocks that unconformably overlie the allochthonous, Proterozoic and Paleozoic rocks along the northern and southern boundaries of the study area.

Slide blocks of Mississippian carbonate rocks, apparently derived from old eastern topographic highs, rest on parts of and, in places, cover the trace of the Hawley Creek thrust.

Allochthonous Proterozoic and Paleozoic rocks on the structurally highest Hawley Creek thrust plate include unnamed Proterozoic $\mathrm{Y}$ sandstone, Ordovician Kinnikinic Quartzite, syenite and granite of the Ordovician Beaverhead Mountains pluton (Beaverhead pluton of Scholten and Ramspott, 1968), dolomite, limestone, and sandstone of the Devonian Jefferson Formation, siltstone and mudstone of the Devonian Sappington Member of the Three Forks Formation, and limestone, siltstone, and mudstone of the Mississippian McGowan Creek Formation. Most of the mining activity adjacent to the study area on the west was concentrated in the Jefferson Formation on the Hawley Creek thrust sheet. Rocks exposed on the lower thrust sheet, the Fritz Creek, differ from those on the Hawley Creek thrust plate in that: (1) the Ordovician Kinnikinic Quartzite is thin or missing entirely as in the eastern part of the study area; (2) only small apophyses of the Beaverhead Mountains pluton are present; and (3) the entire Upper 


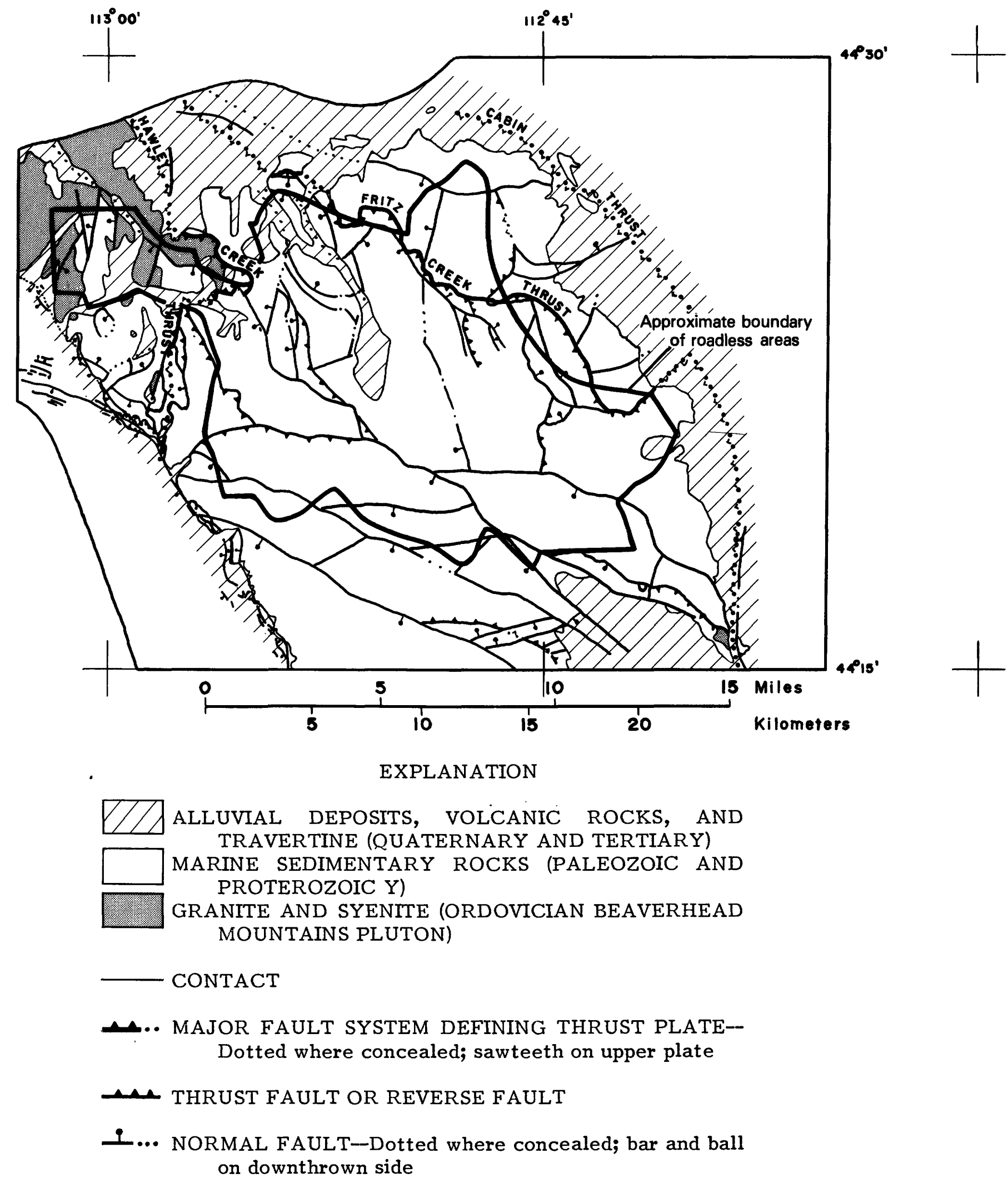

Figure 2.-Generalized geologic map of the Italian Peak and Italian Peak Middle Roadless Areas. 
Mississippian and part of the Pennsylvanian carbonate bank sequences are present and comprise most of the outcrop area. Formations included in these carbonate bank sequences are, in ascending order: Middle Canyon, Scott Peak, South Creek, Surrett Canyon, Big Snowy, Bluebird Mountain, and Snaky Canyon (Pennsylvanian part) Formations. Rocks present on the Cabin plate in the north and east parts of the study area, beneath the Fritz Creek thrust, include: Proterozoic $Y$ sandstone, shale, siltstone and limestone of the McGowan Creek and Three Forks Formations, the Middle Canyon and Scott Peak Formations, a thin shaly limestone interval assigned to the South Creek and Surrett Canyon Formations undivided, the Big Snowy and Bluebird Mountain Formations, and the lower part of the Snaky Canyon Formation. No Mesozoic rocks are present in the study area though Triassic rocks crop out both to the north and south (Lucchitta, 1966; Skipp, Hoggan, and others, 1979).

Unnamed Proterozoic $Y$ sedimentary rocks of shallow marine origin consist of more than $1,500 \mathrm{ft}$ of sandstone and shale. Six of eight rock-chip samples analyzed spectrographically showed no anomalous concentrations of elements. Two similar samples, from just north and south of the area boundary, contained 0.5 and $2.0 \mathrm{ppm}$ silver and up to $300 \mathrm{ppm}$ lead. Therefore the rocks do not seem to be important hosts for mineralization.

Middle Ordovician Kinnikinic Quartzite, ranging in thickness from 0 in the east to more than $800 \mathrm{ft}$ in the west, unconformably overlies the Proterozoic sandstone in the western part of the area. Where present, it forms ledges and cliffs. This formation may have provided a conduit for mineralizing fluids before diagenetic silicification. Weak anomalous metal concentrations were found in this unit in the southern part of the Birch Creek mining district adjacent to higher grade carbonate-hosted ore bodies (Shenon, 1928; Anderson and Wagner, 1944).

The Beaverhead Mountains pluton makes up a large part of the northwest prong of the study area where it comprises the leading edge of the Hawley Creek thrust plate (fig. 2). Apophyses of the pluton also are present on the hanging wall of the Black Mountain thrust just southeast of the study area (fig. 2; Skipp, Prostka, and Schleicher, 1979) and beneath the Hawley Creek thrust in a smali outcrop at the head of Irish Canyon in the study area.

The Beaverhead Mountains pluton consists of medium- to coarse-grained granite and leucosyenite passively emplaced at shallow depths during Middle to Late Ordovician time (Ramspott, 1962; Scholten and Ramspott, 1968; Skipp, 1981). Rocks of the allochthonous pluton are weakly mineralized. PreMiddle Devonian uplift and erosion followed intrusion of the Beaverhead Mountains pluton, and the Upper Devonian Jefferson Formation, where it is present, unconformably overlies Kinnikinic Quartzite or Proterozoic sandstone within the area.

The Jefferson Formation consists of about 0-215 $\mathrm{ft}$ of dolomite, minor dolomitic limestone, and limestone-dolomite breccia above a basal sandstone or conglomeratic sandstone. The dolomite is medium gray to light olive gray, finely crystalline with thin sandy streaks, thin to medium bedded, and weathers light olive gray and gray. The limestone present locally at the top of the Jefferson is medium gray, locally porous with angular solution cavities (Scholten and Ramspott, 1968), and weathers yellowish brown and gray. The carbonate portion of the Jefferson Formation in the study area is interpreted to have been deposited in a shallow marine subtidal environment near the boundary between the continental shelf and the cratonic platform (Poole and others, 1977, p. 56). Angular solution cavities and limestone-dolomite breccias in the formation probably are mainly evaporite solution features (Poole and others, 1977). Locally, the Jefferson Formation has been removed by Late Devonian (pre-Sappington) erosion. Dolomites of the Jefferson Formation host the mineralized bodies of the adjacent Birch Creek mining district and are weakly anomalous in base metals in most samples analyzed.

The Upper Devonian Sappington Member of the Three Forks Formation is reported by Sandberg (1975, p. E5) to consist "mainly of grayish-black chertified and silicified siltstone as much as 75 feet thick" in the souihern Beaverhead Mountains. A basal lag sandstone, interbedded shale, and large limestone concretions also are present (Scholten and Ramspott, 1968, p. 15; Sandberg, 1975, p. E5; Sandberg and Poole, 1977). Weakly anomalous uranium and vanadium, silver, and base metals are common in the Sappington Member.

The Lower Mississippian McGowan Creek Formation is present throughout the study area and ranges in thickness from about 300 to $600 \mathrm{ft}$. It consists of a basal limestone (about 130-400 ft thick) and overlying shale and siltstone (about $150 \mathrm{ft}$ thick). The limestone is medium dark gray to dark gray, aphanic, silty and argillaceous, even bedded, weathers light olive gray to medium light gray, and has been sheared between the underlying and overlying shale and siltstone sequences. Overlying shales and siltstones are carbonaceous, noncalcareous to slightly calcareous, and contain a few limestone interbeds. The McGowan Creek Formation "is correlative on the basis of conodont fauna to all of the Lodgepole Limestone and the lower part of the Mission Canyon Limestone in southwestern Montana" (Sandberg, 1975, p. E9).

Anomalous uranium values are restricted stratigraphically to the McGowan Creek Formation in the Heart Mountain and Nicholia Canyon areas south and west of the study area according to Wodzicki and Krason (1981, p. 42). Sheared and silicified samples of the McGowan Creek yielded higher concentrations of uranium than samples that were not sheared or silicified, but both were anomalous (Wodzicki and Krason, 1981, p. 42-44). One sample of McGowan Creek shale collected in the study area was weakly anomalous in vanadium, silver, and base metals. Two samples of limestone were within the normal range of background abundances.

The McGowan Creek Formation is overlain conformably by the thick (approximately 2,000 ft) Upper Mississippian carbonate-bank sequence consisting of, in ascending order, the Middle Canyon, Scott Peak, South Creek, and Surrett Canyon Formations (Huh, 1967; Rose, 1976; Skipp, Sando, and Hall, 1979). The Middle Canyon Formation shows weak anomalies in silver and base metals where it rests in fault contact on the Hawley Creek thrust sheet outside the study area and in adjacent areas along the western border of the study area. The main body of Upper Mississippian limestone, however, shows no anomalous 
metal values except in the northeastern part of the area where limestones of the lower part of the Scott Peak Formation locally have been altered diagenetically to dolomite and magnesian limestone. One rock-chip sample of three from this zone was weakly anomalous in base metals.

The Upper Mississippian Big Snowy and Bluebird Mountain Formations, consisting of about $500 \mathrm{ft}$ of black shale and sandy limestone and about $300 \mathrm{ft}$ of very fine grained sandstone and quartzite, respectively, are present above the Upper Mississippian carbonate bank sequence. Four limestone samples and one shale sample of the Big Snowy Formation were weakly anomalous in base metals. The shale sample was also weakly anomalous in silver.

About 2,000 ft of the Pennsylvanian part of the Snaky Canyon Formation gradationally overlies the Bluebird Mountain Formation. Limestone, much of it sandy or argillaceous, dolomite, and sandstone make up the formation. No mineralization appears to be associated with this formation in the study area.

Autochthonous Cenozoic volcanic rocks, sedimentary rocks, and sediments in the area consist of intermediate volcanic rocks, andesitic dikes that may have been feeders to the volcanic rocks, rhyolite ash-flow tuffs, and several gravels of both Tertiary and Quaternary age. Of these units, only two of five samples of the dikes were weakly anomalous in base metals in the Italian Peak Roadless Areas. Travertine deposits located outside the area have been quarried locally for decorative building stone.

\section{GEOCHEMISTRY}

A reconnaissance geochemical study to assess the mineral resource potential of the Italian Peak Roadless Areas was undertaken by the U.S. Geological Survey in 1980-82 (Antweiler and others, in press). Geologic and geographic features of the area that influenced the selection of methods used in the geochemical study were: (1) the preponderance of carbonate rocks; (2) the abundance of faults; and (3) the relatively low annual precipitation. Some drainage basins, such as Nicholia, Divide, Webber, and Willow Creeks have perennial streams that extend to lower elevations outside the study area, but most drainages either lack live streams or have small spring-fed streams that appear, disappear, and then reappear at lower and lower elevations.

Four geochemical sampling media were selected on the basis of the regional characteristics mentioned above: stream-sediment (85 samples), panned concentrates of stream-sediment (20 samples), water (36 samples), and rock chip (192 samples). The rock samples were of two kinds: (1) fresh representative rock samples from the major geologic formations of the area collected to establish the background geochemistry; and (2) altered or mineralized rock samples collected from fault zones or mineralized areas to determine mineral suites and trace-element signatures of mineralized systems.

Stream-sediment samples were passed through minus-80-mesh stainless steel sieves, and only the fine fractions were analyzed. The panned concentrates were examined for heavy minerals and then analyzed. Water samples were divided into an untreated portion that was analyzed for anions and a filtered portion that was acidified with nitric acid right after collection and analyzed for cations. The rock samples were prepared for analysis by crushing, grinding, and pulverizing. All except the water samples were analyzed for 31 elements by the semiquantitative emission spectrographic method (Grimes and Marranzino, 1968) by P. T. Hopkins, Jr., U.S. Geological Survey. Chemical analyses were performed by W. L. Campbell, U.S. Geological Survey, for Au on panned concentrates and mineralized rocks using an atomic absorption procedure described in Ward and others (1969) and on selected samples for $\mathrm{As}, \mathrm{Cu}, \mathrm{Cd}$, $\mathrm{Sb}, \mathrm{Bi}, \mathrm{Ag}, \mathrm{Pb}$, and $\mathrm{Zn}$ using methods described by Viets (1978). Chemical analyses on the water samples were performed by J. B. McHugh, U.S. Geological Survey, for $\mathrm{Cu}, \mathrm{Pb}, \mathrm{Zn}, \mathrm{Mo}, \mathrm{U}, \mathrm{Cl}^{-}, \mathrm{F}^{-}, \mathrm{SO}_{4}=$, and conductivity was analyzed using methods described by Miller and others (1982). Concentrations of $U$ and Th were determined by the U.S. Geological Survey laboratories, Denver, Colo., using a delayed neutron activation technique.

Separate analytical data sets were prepared for each sample type. Analytical results of all elements showing significant concentration contrasts were plotted to identify suites of elements with anomalous concentrations. Selection of concentrations for the threshold of anomalous values was based on breaks in slope of cumulative frequency curves for $\mathrm{Cu}, \mathrm{Pb}, \mathrm{Zn}$ (chemical values), $U$, and $V$. Spectrographic values for $\mathrm{Ag}, \mathrm{As}, \mathrm{Mo}, \mathrm{Nb}, \mathrm{Sn}$, and $\mathrm{Zn}$ were considered anomalous if they were at or above the detection limit (table 1). A single sample containing anomalous concentrations of metals was not considered to be evidence that a particular site was anomalous, unless other samples from the same area or drainage basin were also anomalous.

The geochemical survey identified geochemical suites of elements that characterize mineralization and rock types, and defined four areas of mineral resource potential, $\mathrm{A}-1, \mathrm{~A}-2, \mathrm{~A}-3$, and $\mathrm{A}-5$.

\section{GEOPHYSICS}

Aeromagnetic (U.S. Geological Survey, 1981) and gravity (Kulik, in press) studies were undertaken as part of the mineral resource evaluation of the Italian Peak Roadless Areas. Geophysical data provide information on the subsurface distribution of rock types that may have associated anomalous mineral concentrations.

The study area is characterized by a broad plateau of moderately high gravity values over the allochthonous Ordovician, Devonian, Mississippian, and Pennsylvanian rocks. Broad low anomalies over low density Tertiary and Quaternary rocks characterize the valleys east and west of the study area. In the northwestern part of the region, low gravity anomalies and high magnetic anomalies are associated with rocks of the Beaverhead Mountains pluton $(\mathrm{Ob})$ where they crop out. The pluton is weakly anomalous in silver and base metals as described in the section on the mineral resource assessment of area A-1. Relatively low gravity values spatially correlated with high magnetic values along the western edge of the study area indicate that the pluton probably underlies those areas at shallow depths. A low magnetic anomaly over some of the outcropping rocks of the pluton in the northwest prong of the study area suggests that the pluton is 
anomalously thin there. Local high and low magnetic anomalies of high amplitude are associated with the intermediate volcanic rocks $\left(\mathrm{T}_{\mathrm{v}}\right)$ that crop out in the northern part of the study area. These rocks do not appear to be mineralized.

High gravity anomalies seem to be spatially correlated with outcrops of Proterozoic $\mathrm{Y}$ rocks (Ys), but these rocks do not appear to be geochemically anomalous and their presence in the subsurface is not important to the mineral resource evaluation.

\section{MINING DISTRICTS AND MINERALIZED AREAS}

\section{Mining history}

The northwest corner of the Italian Peak Roadless Areas includes the north part of the Birch Creek mining district, a signficant lead-silver district in Idaho. The district extends from Willow Creek (fig. 3) for $25 \mathrm{mi}$ to the south-southeast. Lead, silver, and zinc minerals were first discovered at the Viola mine, just west of the study area (fig. 3 , no. 10) in 1881 , and by 1890 all major mines and prospects in the district had been located (Anderson and Wagner, 1944, p. 14). Total production of $\$ 2.5$ to $\$ 5.0$ million in lead, silver, and zinc was primarily from the Viola mine and a few adjacent mines (Anderson and Wagner, 1944, p. 14). All production was outside the Italian Peak Roadless Areas. Recently a few thousand tons of ore was mined from the Viola mine for trace-element fertilizer additive and a drilling program was conducted in the district in 1977 (Ed Wilson, owner, written commun., 1979). The probable site of an old placer mine (fig. 3 , no. 3) was found in Willow Creek, but there is no recorded placer gold production, and samples collected during this study contained no gold.

No production has occurred from the Heart Mountain mineralized area just south of the study area. Most prospecting occurred during the post-World War II "uranium boom," and an exploratory drilling program with a total footage of 4,882 in 18 holes was conducted at the Elkhorn Group prospect (fig. 3, no. 25) during 1977 (Henry Childs, Chilco Mining Co., claimant, written commun., 1980).

The total number of historic claims located in or near the study area could not be deterinined; there are, however, about 250 active claims, of which about 10 are in the study area. Of the 250 active claims, 100-200 are in the Heart Mountain area. The remainder are in the Birch Creek mining district. One patented claim group of 16.25 acres encompasses the Viola mine.

\section{Methods of study}

The U.S. Bureau of Mines examined 33 mines and prospects in and near the Italian Peak Roadless Areas during August and September 1980 (fig. 3, Lambeth and Mayerle, 1983). Of these, only five are within the study area. In the field, claims, prospects and mines were examined, sampled, and mapped where warranted. Lode (chip and grab) samples (311) were taken from mineralized structures or mine and prospect dumps. Reconnaissance placer samples (35) were taken from streams and gullies in the field. Lode samples were crushed, pulverized, and split. Each sample was examined for abnormal radioactivity to test for uranium, and checked for fluorescence to test for possible tungsten. Most samples were fire assayed for gold and silver. At least one sample from each mineralized feature was analyzed by semiquantitative spectrographic methods; elements in anomalous concentrations were then analyzed by atomic absorption, cold-vapor atomic absorption, colorimetric, X-ray flourescent, or inductively coupled argon spectrometric quantitative methods as required. Placer samples, which were partially concentrated in the field, were further concentrated on a Wilfley table.

Production records were compiled from U.S. Bureau of Mines public production records (Western Field Operations Center, Seattle, Wash.). Idaho Bureau of Mines and Geology pamphlets and maps (Shenon, 1928; Anderson and Wagner, 1944; Mitchell and others, 1981), and reports of the State Inspector of Mines in annual reports of the mining industry in Idaho also published by the Idaho Bureau of Mines and Geology (Bell, 1906).

\section{Mineralized areas}

\section{Birch Creek mining district}

The common ore minerals in the north end of the Birch Creek mining district are secondary oxides, carbonates, and silicates of lead, zinc, and copper with accessory silver. Common gangue minerals are barite, limonite, manganese oxides, jasper, gypsum, siderite, hematite, and quartz. Remnants of the primary sulfide minerals galena, sphalerite, chalcopyrite, pyrite, and tetrahedrite (Anderson and Wagner, 1944, p. 16) are preserved locally. The ore bodies in the district have been described as oxidized replacement deposits of lead, silver, zinc, and copper derived from magmatic hydrothermal fluids that migrated from depth along the range front fault system (Shenon, 1928; Anderson and Wagner, 1944). However, the deposits have been reclassified as possible basinmargin, carbonate-hosted, lead-silver-zinc deposits stratabound within the Devonian sedimentary rocks as a result of this study (Lambeth and Mayerle, 1983). The depositional environment of the dolomite host rock of the Jefferson Formation has been described as shallow marine subtidal, locally evaporitic, near the boundary between the continental shelf and the cratonic platform possibly east of an island arc and associated inner-arc basin (Poole and others, 1977, p. 56). The requirements for basin-margin, carbonatehosted deposits are: (1) a basinward metal source; (2) permeable migration conduits; (3) a basin-margin host rock; and (4) an impermeable cap. A metal source could have been provided by the destruction of the western, metal-rich arc terrain supplemented by cratonic erosion sources and concentration in the adjacent back-arc basin. The migration conduit may have been the Kinnikinic Quartzite before secondary silicification, and the principal host rock is the cratonmargin Devonian dolomite. An impermeable cap could have been provided by the low permeability shale and silicified siltstone of the Sappington Member of the Three Forks Formation and the shale and siltstone of the upper part of the McGowan Creek Formation. During lithifienation of the back-arc basin sediments, the metal ions may have been mobilized, and then migrated as acidic chloride complexes up the hydraulic gradient toward the cratonic platform along faults and 


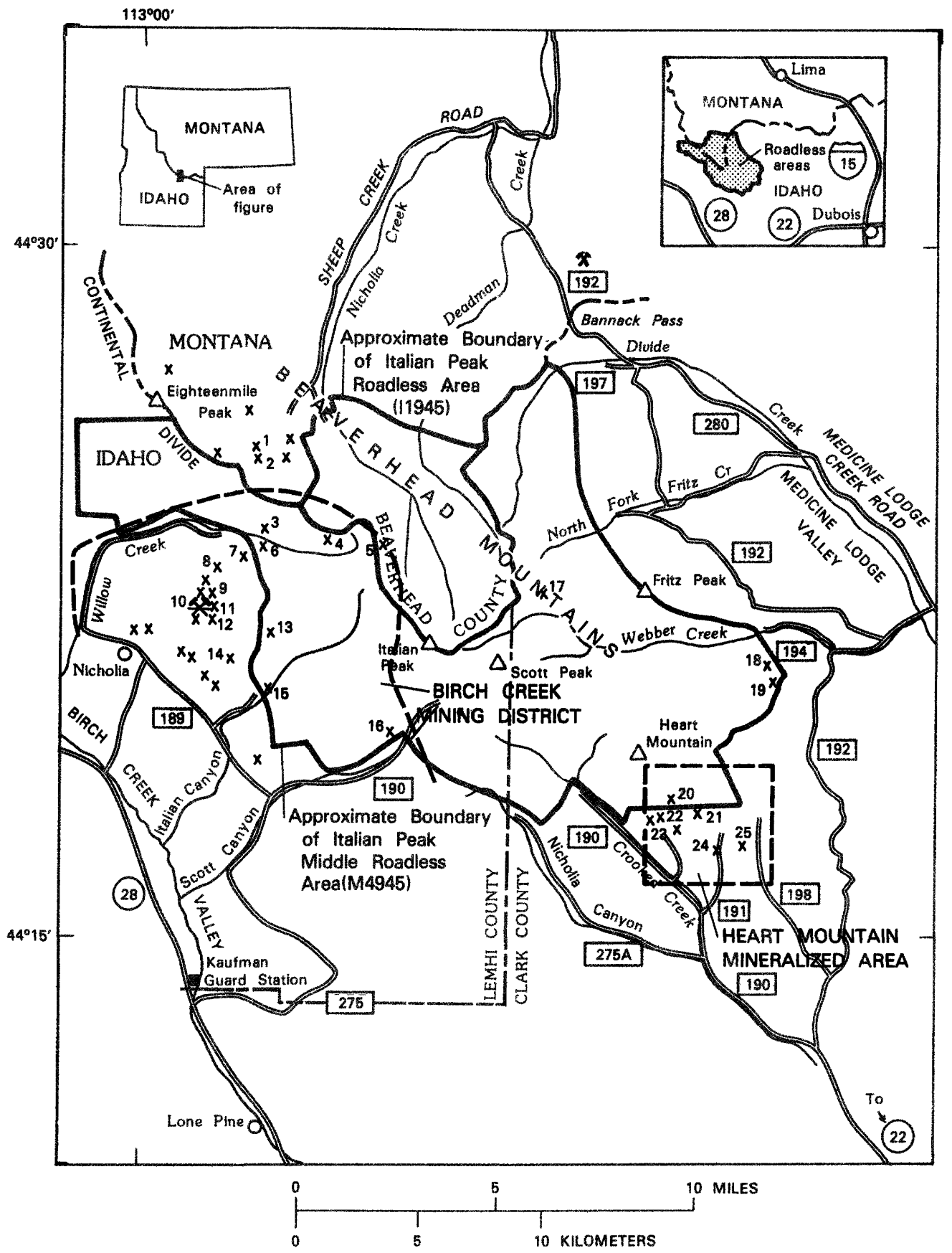

Figure 3.--Map showing mines and prospects in and near the Italian Peak and Italian Peak Middle Roadless Areas. Numbered prospects are those reported on by the U.S. Bureau of Mines in the accompanying table; unnumbered prospects were noted but not described. Approximate outlines of Birch Creek mining district and Heart Mountain mineralized area from Lambeth and Mayerle (1983). 
permeable formations. The metal-rich fluids may have traveled cratonward through permeable sandstones of the Kinnikinic Quartzite and deposited their metals upon contact with the overlying Devonian carbonate rocks. Reductive sulfide ions could have been provided by evaporites in the Devonian Jefferson Formation.

All mines in the northern part of the district were collapsed, however, and the relationship of mineralization to host rocks could not be examined by the U.S. Bureau of Mines investigators. However, descriptions of the mineralized bodies by Shenon (1928) and Anderson and Wagner (1944) indicate that they had the characteristics of stratabound deposits. Prospects scattered through this area are spatially related to the Jefferson Formation, supporting the stratabound concept of the base and precious metal potentials.

\section{Heart Mountain mineralized area}

The uranium and vanadium deposits of the Heart Mountain mineralized area are classified by Wodzicki and Krason (1981) as a stratiform, black-shale-hosted type. Concentrations of uranium and vanadium present in the metal-rich shale and siltstone are enhanced where the shales have been sheared, brecciated, and silicified (Wodzicki and Krason, 1981).

\section{Mines and prospects}

Prospects are scattered throughout the study area, and 33 of them are described in Lambeth and Mayerle (1983). Most of them are in the Jefferson and McGowan Creek Formations, indicating the probable stratabound nature of base and precious metals and of uranium. Most of the prospects in the extreme northwest corner of the area have been excavated in zones of weakly anomalous uranium in syenite of the Beaverhead Mountains pluton. Local lenses of phosphatic shale occur in upper Paleozoic rocks, but none constitutes a resource.

\section{ASSESSMENT OF MINERAL RESOURCE POTENTIAL}

\section{Introduction}

The mineral resource potential of the Italian Peak Roadless Areas is classified as low to moderate in the framework of three categories of evaluationhigh, moderate, and low. Areas with high mineral resource potential would be those having an excellent probability that mineral deposits exist; none of these were identified in the study area. Areas with moderate mineral resource potential are those for which there is a reasonable chance for the existence of mineral deposits based on geologic, geochemical, and geophysical evidence and the presence of mines and prospects or other evidence of mining activity; one such area was identified in the study area. Areas with low mineral resource potential either lack evidence to support a favorable genetic model, lack indicators of mineralization, including the presence of mines and prospects, or have no favorable combination of geologic, geochemical, and geophysical factors; four of these were identified in the study area. The potential for geothermal resources, placer gold, and decorative stone also was evaluated, and none was identified. The potential for gas is considered low and is discussed. There is no potential for oil.
Silver and base metal mineralization related to the Beaverhead Mountains pluton (area $A-1$ )-Low mineral resource potential

Area A-1 (fig. 4) is in the northwestern part of the study area where rocks of the Beaverhead Mountains pluton either crop out or their presence in the shallow subsurface is indicated by gravity and aeromagnetic data. Area A-1 overlaps the western part of area A-2 (fig. 4). The suite of metals occurring in anomalous concentrations associated with this area consists of barium, molybdenum, silver, copper, lead, tin, and niobium identified primarily from rocks of the pluton. Anomalous concentrations are low (that is, not much greater than the threshold), but values as high as 1,000 ppm molybdenum and 2,000 ppm lead were obtained locally (Antweiler and others, in press). The greatest abundance of tin obtained in one panned concentrate reached $100 \mathrm{ppm}$, a concentration far too low to indicate the possibility of a tin resource.

The mineral resource potential of area $A-1$ is low. Geochemical anomalies are weak, and no production has been recorded from the rocks of the Beaverhead Mountains pluton near this area.

Stratabound silver and base metal mineralization in the Devonian Jefferson Formation (area A-2)Moderate to low mineral resource potential

Area $\mathrm{A}-2$ is the most altered and mineralized part of the study area. It includes the Park prospect on upper Willow Creek (fig. 3, no. 4), the mines and prospects in the vicinity of Viola and Smelter Gulches west of the study area, and the area on both sides of the Continental Divide at the headwaters of Nicholia and Willow Creeks. The suite of elements occurring in anomalous concentrations associated with this area is dominated by zinc, but also includes lead, silver, barium, molybdenum, and, in places, copper and arsenic. Two types of mineralization are associated with area A-2: stratabound and fault controlled. Stratabound mineralization seems to be concentrated primarily in dolomite of the Devonian Jefferson Formation, the host rock of the Viola mine west of the study area. In addition, every analyzed sample of Jefferson dolomite in area A-2 was anomalous in one or more of the elements listed above. A basin-margin, carbonate-hosted mineralization model is indicated for these deposits rather than the hydrothermal origins postulated in earlier literature (Shenon, 1928; Anderson and Wagner, 1944). All of the production west of the study area was from the Devonian Jefferson Formation located on the hanging wall of the Hawley Creek thrust. Geology and geochemistry suggest that the formation on the foot wall of the thrust in the study area may be less mineralized. Area $\mathrm{A}-2$ is classified as having a moderate to low resource potential for silver, lead, and zinc as it is adjacent to a district that has had production.

Silver and base metal mineralization related to

faulting in Mississippian sedimentary rocks

(areas $\mathrm{A}-2$ and $\mathrm{A}-3$ )-Low to moderate mineral resource potential

Area $A-2$ in the west-central part of the study area contains products of both stratabound mineralization discussed earlier, and fault-controlled 


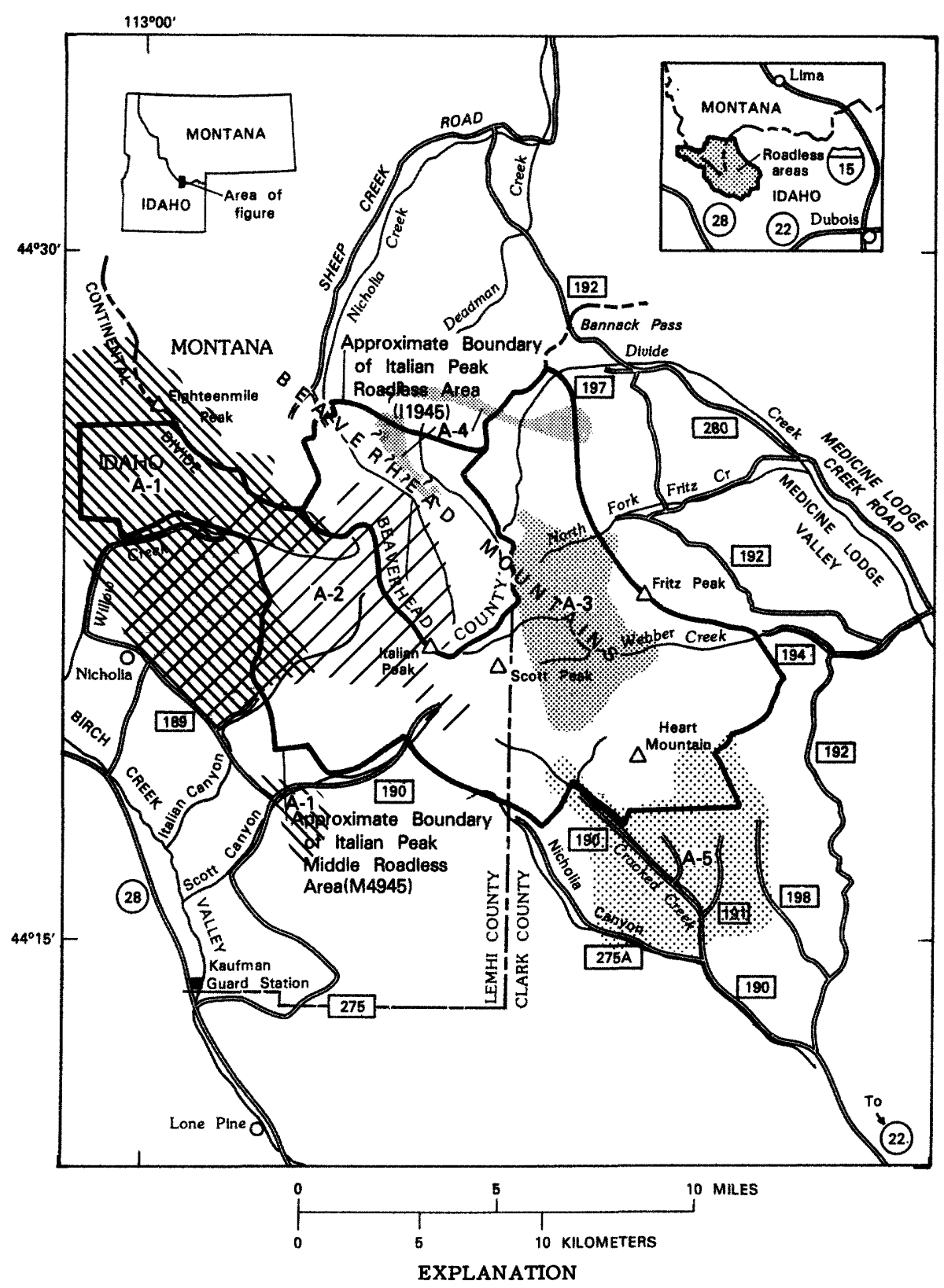

AREA A-1-Low potential for silver, molybdenum, lead,
and zinc
AREA A-2-Moderate to low potential for silver, lead,
and zinc
AREA A-3-Low to moderate potential for silver, lead,
and zinc
AREA A-4-Low potential for silver, lead, and zinc
AREA A-5-Low to moderate potential for uranium,
vanadium, silver, lead, and zinc

Figure 4.-Map showing areas of mineral resource potential in the Italian Peak and Italian Peak Middle Roadless Areas. 
mineralization. Mineralized rock occurs along faults and fractures at and near the Park prospect in the upper reaches of Willow Creek (fig. 3 , no. 4), in the slide blocks of Mississippian limestones that overlap both the hanging wall and foot wall of the Hawley Creek thrust and probably in the Mississippian limestones of the foot wall of the Hawley Creek thrust along the western margin of the study area. Geochemical anomalies based both on rock and stream-sediment samples are present in these areas. Because the mineral occurrences are in rocks stratigraphically and (or) structurally above the Devonian Jefferson Formation, mineralization may have resulted from remobilization and redeposition of metals derived from underlying stratabound deposits. Ages of mineralization support this concept. The stratabound mineralization is at least of post-Devonian and pre-thrusting (pre-Late Cretaceous) age, and the fault-controlled mineralization associated with young normal faults in the vicinity of the Park mine is of post-thrusting and pre-middle Eocene age (Skipp, in press). The suite of elements occurring in anomalous concentrations associated with fault-controlled mineralization is the same, or nearly the same, as that associated with the stratabound deposits. The area has low to moderate resource potential for silver, lead, and zinc because even though geologic factors and geochemical anomalies indicate a favorable environment for ore deposits, no production has come from this type of mineralization.

Area $\mathrm{A}-3$ in the east-central part of the study area includes the part of the drainage of the North Fork of Webber Creek east of the normal fault along which undivided Mississippian and Devonian rocks have been mapped. Anomalous metal values near the fault zone and at the contact of the Devonian rocks with Proterozoic $\mathrm{Y}$ sandstones are dominated by zinc, and include barium, molybdenum, and locally, copper, lead, or vanadium. In this area, also, both stratabound and fault controlled mineralization may be present, and though potential resources for silver and base metals may occur, the geologic setting is not as favorable as in area $\mathrm{A}-2$, and the area is considered to have a low to moderate mineral resource potential. Faults are fewer; the Kinnikinic Quartzite is not present to have provided a favorable conduit for metal-rich fluids, and the area lies several more miles upgradient from a hypothetical western metal source. Several geochemical anomalies were noted, however, and considerable prospecting was done in the basal Devonian Jefferson Formation.

Stratabound silver and base metal mineralization in the Upper Mississippian Scott Peak Formation (area $\mathrm{A}-4$ )-Low mineral resource potential

Area A-4 is in the northeastern part of the study area, just south of the Divide Creek fault, where dolomite and magnesian limestone of probable diagenetic origin occur locally in the lower beds of the Upper Mississippian Scott Peak Formation just above the contact with the Middle Canyon Formation. The dolomite and magnesian limestone are present on both the hanging wall and foot wall of the Fritz Creek thrust fault (figs. 2 and 4). They are fine to coarse grained and range in color from medium dark gray to dark olive gray to brownish gray. Weathered colors are mostly olive gray and brownish gray. Fractured black chert is present locally. The dolomite grades laterally into the pure carbonate bank limestone of the main part of the Scott Peak Formation. The southern boundary between dolomite and limestone is steep and may be a fault or shear zone, but colluvium obscures these relationships. Beds on either side of the steeply dipping contact have gentle dips. Diagenetic alteration of the limestone to dolomite preceded thrusting, as the dolomite and magnesian limestone are thrust over unaltered limestones of the same formation.

Geochemical analyses of two whole rock samples of magnesian limestone showed they were not mineralized, but an analysis of one sample of ferrodolomite from the northern border of the study area indicated weak anomalies in lead, chromium, and nickel.

This ferrodolomite occurrence has the characteristics of a potential stratabound lead-zinc deposit as outlined by W. P. Pratt (1982, p. 156-157) in that dolomite is present "within a few hundred meters of *** lateral transition into limestone," and base metal values appear to be slightly higher than average. The dolomite occurrences have not been prospected and need further investigation. Area A-4 has a low mineral resource potential for base metals and silver.

Uranium-vanadium stratabound mineralization in Devonian and Mississippian rocks south of Heart Mountain (area A-5)-Low to moderate mineral resource potential

Area A-5 is located in the southeastern part of the area south of Heart Mountain. It includes the lower parts of the drainages of Grouse, Myers, and Crooked Creeks. Anomalous metal values for uranium, zinc, lead, molybdenum, silver, and arsenic occur mainly in prospect pits near the southern boundary of the study area. Samples from these prospect pits contain up to 0.63 percent vanadium, 0.5 percent zinc, 1 percent lead, 0.4 percent copper, and $0.3 \mathrm{oz}$ of silver per ton of ore (Antweiler, 1983; Lambeth and Mayerle, 1983). Mineralization is most likely both stratabound and fault controlled, and mineralized rocks are present in the siltstones of the Sappington Member of the Devonian Three Forks Formation and the black shales and siltstones of the Mississippian McGowan Creek Formation, particularly where they have been brecciated, sheared and silicified. The McGowan Creek Formation has considerably higher background levels of radioactivity (about $40 \mathrm{ppm}$ uranium) than do most other rocks in the area, and where the formation has been sheared and silicified, and in "silicified, porous, silica-rich channels" in the formation, the concentrations average about $200 \mathrm{ppm}$ uranium (Wodzicki and Krason, 1981). Anomalous radioactivity levels have also been observed in the siltstones of the Sappington Member in this study.

The area has a low to moderate potential for uranium, vanadium, silver, lead, and zinc, but no production in or adjacent to the study area has taken place, although 100-200 claims currently (1982) are held. 


\section{Rock products-decorative building stone}

No potential for decorative building stone exists within the boundaries of the Italian Peak Roadless Areas. Decorative stone has been quarried from Miocene travertine deposits about $3 \mathrm{mi}$ northeast of the study area for several decades.

\section{Geothermal resources}

No known geothermal potential exists in the Italian Peak Roadless Areas.

\section{Oil and gas}

The potential for hydrocarbon reserves in eastcentral Idaho and southwestern Montana has been reviewed by Scholten (1967), Ruppel (1978), Skipp (1979), Perry and others (1981), and Perry and others (1983), and is considered low to moderate. The oil and gas potential for the Italian Peak Roadless Areas is considered low for the reasons discussed below. Although the area is in the northern extension of the Idaho-Wyoming thrust belt, a province that has been productive to the south in Wyoming, the part of the belt in the study area has been pulled apart by numerous Tertiary extension faults. In addition, conodonts from Mississippian limestones on the Fritz Creek and Cabin thrust plates (Skipp, in press) have yielded Conodont Alteration Index (CAI) values of 4 to 5 1/2 (Skipp, Prostka, and Schleicher, 1979), indicating that these limestones have been subjected to temperatures of $190^{\circ} \mathrm{C}$ or more (Epstein and others, 1977). Any hydrocarbons present in the rocks on these thrust plates would be in a state of late postmature thermal maturity, and dry gas would be the only possible resource (Perry and others, 1981).

Paleozoic rocks of the Medicine Lodge thrust plate probably underlie eastern and northeastern parts of the area at depths of several thousand feet (Skipp, in press). Limestones from the front of this plate have CAI values of $11 / 2$ to 3 (Skipp, in press; Perry and others, 1981). These lower values are from the exposed leading edge of the thrust. Higher CAI values from the Medicine Lodge plate outside the map area indicate a thermal history similar to that of the overlying plates (Skipp, in press).

It is possible that rocks of the Tendoy thrust sheet exposed east of the study area (Scholten and others, 1955; Skipp and Hait, 1977; Perry and others, 1981; Perry and others, 1983) may extend westward beneath the easternmost edge of study area at depths below sea level (Skipp, in press). Outcrops of rocks of the Tendoy plate to the east are thermally immature, and are not in the oil generation window (Perry and others, 1983), and both potential petroleum source beds and reservoir rocks are present. At depths below sea level beneath the study area (Skipp, in press), however, rocks on the Tendoy thrust plate probably have been subjected to temperatures similar to those of the overlying plates. Also, as these rocks are present at the surface nearby, it is likely that any associated hydrocarbons in the study area would have migrated up dip to the east. Thus, geologic conditions suggest that there is no resource potential for oil in the area. The resource potential for gas is considered low because, although it may be present at depth, the existence of dense Paleozoic rocks at the surface precludes the effective use of reflection seismic exploration techniques, and random drilling is costly.

\section{REFERENCES}

Anderson, A. L., and Wagner, R. W., 1944, Lead-zinccopper deposits of the Birch Creek district, Clark and Lemhi Counties, Idaho: Idaho Bureau of Mines and Geology Pamphlet 70, 43 p.

Antweiler, J. C., Campbell, W. L., and Fox, J. P., in press, Geochemical map of the Italian Peak and Italian Peak Middle Roadless Areas, Beaverhead County, Montana, and Clark and Lemhi Counties, Idaho: U.S. Geological Survey Miscellaneous Field Studies Map MF-1601-C, scale 1:62,500.

Bell, R. N., 1906, Report of the state inspector of mines 1905: Idaho Bureau of Mines and Geology, Seventeenth Annual Report of the Mining Industry of Idaho, p. 93.

Epstein, A. G., Epstein, J. B., and Harris, L. D., 1977, Conodont color alteration-an index to organic metamorphism: U.S. Geological Survey Professional Paper 995, $27 \mathrm{~F}$.

Grimes, D. J., and Marranzino, A. P., 1968, Directcurrent arc and alternating current spark emission spectrographic field methods for the semiquantitative analysis of geologic materials: U.S. Geological Survey Circular 591, 6 p.

Huh, O. K., 1967, The Mississippian system across the Wasatch line, east-central Idaho and extreme southwestern Montana, in Centennial basin of southwest Montana: Montana Geological Society Guidebook, 18th Annual Field Conference, 1967, Billings, Montana, p. 31-62, 1 pl., 13 figs.

Kirkham, V. R. D., 1927, A geologic reconnaissance of Clark and Jefferson, and parts of Butte, Custer, Fremont, Lemhi, and Madison Counties, Idaho: Idaho Bureau of Mines and Geology Pamphlet 19, $47 \mathrm{p}$.

Kulik, D. M., in press, Complete Bouguer gravity and aeromagnetic map with interpretations of the Italian Peak and Italian Peak Middle Roadless Areas, Beaverhead County, Montana, and Clark and Lemhi Counties, Idaho: U.S. Geological Survey Miscellaneous Field Studies Map MF1601-D, scale $1: 62,500$.

Lambeth, R. H., and Mayerle, R. T., 1983, Mineral investigation of the Italian Peak RARE II area (No. I-1945), Beaverhead National Forest, Beaverhead County, Montana, and Italian Peak Middle RARE II area (No. M-4945), Targhee National Forest, Clark and Lemhi Counties, Idaho-Summary Report: U.S. Bureau of Mines Open-File Report MLA 53-83, 26 p.

Lucchitta, B. K., 1966, Structure of the Hawley Creek area, Idaho-Montana: University Park, Pennsylvania State University $\mathrm{Ph}$. D. thesis, $203 \mathrm{p}$.

Miller, W. B., Ficklin, W. H., and Learned, R. E., 1982, Hydrogeochemical prospecting for porphyry copper deposits in the tropical-marine climate of Puerto Rico: Journal of Geochemical Exploration, v. 16, p. 217-233.

Mitchell, V. E., Strowd, W. B., Hustedde, G. S., and Bennett, E. H., 1981, Mines and prospects of the Dubois quadrangle, Idaho: Idaho Bureau of Mines and Geology Mines and Prospects Map Series, 22 p. 
Perry, W. J., Jr., Ryder, R. J., and Maughan, E. K., 1981, The southern part of the Southwest Montana Thrust Belt: A preliminary reevaluation of structure, thermal maturation and petroleum potential: Montana Geological Society Field Conference and Symposium Guidebook, Southwest Montana, p. 261-273.

Perry, W. J., Jr., Wardlaw, B. R., Bostick, N. H., and Maughan, E. K., 1983, Structure, burial history, and petroleum potential of the frontal thrust belt and adjacent foreland, southwest Montana: American Association of Petroleum Geologists Bulletin, v. 67, no. 5, p. 725-743.

Poole, F. G., Sandberg, C. A., and Boucot, A. J., 1977, Silurian and Devonian paleogeography of the western United States, in Pacific Coast Paleogeography Symposium, lst, Bakersfield, California, 1977, Paleozoic paleogeography of the western United States: Society of Economic Paleontologists and Mineralogists, Pacific Section, p. 39-65.

Pratt, W. P., 1982, A prospecting model for stratabound lead-zinc (barite-fluorite deposits ("Mississippi Valley-type" deposits), in Erickson, R. E., compiler, Characteristics of mineral deposit occurrences: U.S. Geological Survey Open-File Report 82-795, p. 155-157.

Ramspott, L. D., 1962, Geology of the Eighteenmile Peak area and petrology of the Beaverhead Pluton: University Park, Pennsylvania State University $\mathrm{Ph}$. D. thesis, $215 \mathrm{p}$.

Rose, P. R., 1976, Mississippian carbonate shelf margins, western United States: U.S. Geological Survey Journal of Research, v. 4, no. 4, p. 449466.

Ruppel, E. T., 1978, Medicine Lodge thrust system, east-central Idaho and southwest Montana: U.S. Geological Survey Professional Paper 1031, 23 p.

Ryder, R. T., and Scholten, Robert, 1973, Syntectonic conglomerates in southwest Montana-their nature, origin, and tectonic significance: Geological Society of America Bulletin, v. 84, p. 773-796.

Sandberg, C. A., 1975, McGowan Creek Formation, new name for Lower Mississippian flysch sequence in east-central Idaho: U.S. Geological Survey Bulletin 1405-E, $11 \mathrm{p}$.

Sandberg, C. A., and Poole, F. G., 1977, Conodont biostratigraphy and depositional complexes of Upper Devonian cratonic-platform and continental-shelf rocks in the Western United States, in Murphy, M. A., Berry, W. B. N., and Sandberg, C. A., eds., Western North America; Devonian: Riverside, University of California, Campus Museum Contribution 4, p. 144-182.

Scholten, Robert, 1967, Structural framework and oil potential of extreme southwestern Montana: Montana Geological Association Guidebook, 18th Annual Field Conference, p. 7-19.

Scholten, Robert, Keenman, K. A., and Kupsch, W. O., 1955, Geology of the Lima region, southwestern Montana and adjacent Idaho: Geological Society of America Bulletin, v. 66, no. 4, p. 345-404.

Scholten, Robert, and Ramspott, L. D., 1968, Tectonic mechanisms indicated by structural framework of central Beaverhead Range, Idaho-Montana: Geological Society of America Special Paper 104, $71 \mathrm{p}$.
Shenon, P. J., 1928, Geology and ore deposits of the Birch Creek district, Idaho: Idaho Bureau of Mines and Geology Pamphlet 27, 25 p.

Skipp, Betty, 1979, Allochthons along the northeast margin of the Snake River Plain, IdahoRevisited-Up date on the Wyoming-Idaho-Utah Thrust Belt: Wyoming Geological Survey Public Information Circular 10, p. 25-26.

1981 , A synopsis of the structure and stratigraphy of south-central Idaho--Contributions by the U.S. Geological Survey since 1975: Montana Geological Society Guidebook, Field Conference, Southwest Montana, Dillon, Montana, p. 365-372. in press, Geologic map and cross sections of the Italian Peak and Italian Peak Middle Roadless Areas, Beaverhead County, Montana, and Clark and Lemhi Counties, Idaho: U.S. Geological Survey Miscellaneous Field Studies Map MF$1601-B$, scale $1: 62,500$.

Skipp, Betty, and Hait, M. H., Jr., 1977, Allochthons along the northeast margin of the Snake River Plain, Idaho, in Rocky Mountain thrust belt geology and resources: Wyoming Geological Association Guidebook, 29th Annual Field Conference, Teton Village, Wyoming, 1977, p. 499-515.

Skipp, Betty, Hoggan, R. D., Schleicher, D. L., and Douglass, R. C., 1979, Upper Paleozoic carbonate bank in east-central Idaho-Snaky Canyon, Bluebird Mountain, and Arco Hills Formations and their paleotectonic significance: U.S. Geological Survey Bulletin 1486, $78 \mathrm{p}$.

Skipp, Betty, Prostka, H. J., and Schleicher, D. L., 1979, Preliminary geologic map of the Edie Range quadrangle, Clark County, Idaho, and Beaverhead County, Montana: U.S. Geological Survey Open-File Report 79-845, scale 1:62,500.

Skipp, Betty, Sando, W. J., and Hall, W. E., 1979 1980, Mississippian and Pennsylvanian (Carboniferous) systems in the United StatesIdaho: U.S. Geological Survey Professional Paper 1110 , p. AA1-AA42.

Umpleby, J. B., 1913, Geology and ore deposits of Lemhi County, Idaho: U.S. Geological Survey Bulletin 528, $182 \mathrm{p}$.

U.S. Geological Survey, 1970, Mean annual precipitation, in The National Atlas of the United States of America: p. 97.

1981, Aeromagnetic map of the Italian Peak area, Idaho and Montana: U.S. Geological Survey Open-File Report 81-1162.

Viets, J. G., 1978, Determination of silver bismuth, cadmium, copper, lead, and zinc in geologic materials by atomic absorption spectrometry with tricaprylyl-methylammonium chloride: Analytical Chemistry, v. 50, no. 8, p. 1097-1101.

Ward, F. N., Nakagawa, H. M., Harms, T. F., and Van Sickle, G. H., 1969, Atomic absorption methods of analysis useful in geochemical exploration: U.S. Geological Survey Bulletin 1289,45 p.

Wodzicki, Antoni, and Krason, Jan, 1981, National uranium resource evaluation-Dubois quadrangle, Idaho and Montana: U.S. Department of Energy Report GJQ-008 (81), 67 p. 
: 